\title{
Efficiency of Chemical Ripener Action in Sugarcane. II. Time-Course for the Induction of Growth, Sucrose, and Enzymic Changes by Polaris in Early-Juvenile Sugarcane ${ }^{1}$
}

\author{
Alex G. Alexander ${ }^{2}$
}

\begin{abstract}
The time-course for induction of growth, sucrose, and enzyme changes by Polaris ${ }^{3}$ (N,N-bis [phosphonomethyl] glycine), a commercial sugarcane ripener marketed by Monsanto Agricultural Products Company, was studied with early-juvenile sugarcane propagated by sand culture. The ripener was administered as an aqueous foliar spray containing 3000 $\mathrm{p} / \mathrm{m}$ active ingredient. Plant samples were harvested just prior to treatment and from $8 \mathrm{~h}$ to 10 days thereafter. Acid invertase was significantly repressed within $24 \mathrm{~h}$ and sucrose increased in both leaf and expanding stem tissue within $48 \mathrm{~h}$. The enzymes trehalase and ATP-ase declined in expanding stem tissue by the fourth and tenth day, respectively. Soluble protein was significantly repressed from the seventh day onward. Significant growth repression was first recorded at 7 days. The time-course of Polaris action is discussed in the context of spatially- and biochemically-discrete tasks to be performed within an early-juvenile model.
\end{abstract}

\section{INTRODUTION}

With advent of Polaris as the first commercial cane ripener $(17,11)$, important questions arise as to the most effective use of chemical ripeners among the divergent sugar-planting regions of the world. Efficient usage is predicated upon a working knowledge of the kind of changes brought about in the plant, plus the rapidity with which these changes occur and their persistence in local varieties as locally cultured. This information will be decisive for both the chemical enhancement of natural ripening processes and the synchronization of optimal cane quality with scheduled harvest operations.

${ }^{1}$ Manuscript submitted to the Editorial Board October 7, 1975.

${ }^{2}$ Plant Physiologist, Agricultural Experiment Station, University of Puerto Rico, Mayagüez Campus, Río Piedras, P.R.

${ }^{3}$ Trade names are used in this publication solely for the purpose of providing specific information. Mention of a trade name does not constitute a guarantee or warranty of equipment or materials by the Agricultural Experiment Station of the University of Puerto Rico or an endorsement over other equipment or materials not mentioned. 
Monsanto (11) generalized a Polaris response curve in which optimal sucrose increases are attained between 4 and 10 weeks after treatment. This suggests that chemical activity may continue within a sucrosemanufacturing system almost totally successive to the one sprayed by aircraft. Greenhouse tests have shown optimal Polaris action from 15 to 33 days $(11,1)$, with evidence of invertase changes occurring within 5 days after treatment. In a physiological context adult cane should logically strike a balance between response and recovery within about 3 to 5 weeks after reception of a powerful growth regulator.

Equally important is the rapidity of ripener response that can be relied upon under regional conditions. This is particularly true where high tonnage is stressed with prolonged water and nitrogen treatments, and where local climate and technological factors are not conducive to long term planning of harvest dates. The time-course for Polaris induction of growth, sucrose, and enzymic changes in rapidly-growing plantlets is presented in the present report. The persistence or duration of cane response to hormone-like materials is correctly viewed as a function of the quantity of material administered plus the number and frequency of administrations. The persistence of Polaris action will be treated in a forthcoming article (10).

\section{MATERIALS AND METHODS}

One-eye cuttings of the interspecific hybrid PR 980 were propagated by sand culture with controlled water and nutrient regimes. The theory and methodology of cane plantlet propagation, together with the technology for use of young leaf and meristematic parameters, is detailed in earlier publications $(3,2)$.

At 7 weeks of age, test plants were sprayed with an aqueous Polaris solution containing $3000 \mathrm{p} / \mathrm{m}$ active ingredient plus $0.1 \%$ Tween 20 as wetting agent. Application time was $0630 \mathrm{~h}$ on June 4, shortly after sunrise. Control plants were sprayed with Tween 20 in distilled water. There were three replications.

Sugarcane samples consisting of six uniform plants per replicate were harvested just prior to the $0630 \mathrm{~h}$ application. Subsequent harvests were made $8 \mathrm{~h}$ later, and at 1,2, 4, 7 and 10 days after Polaris administration (each at $0630 \mathrm{~h}$ ). Green weight values were recorded for whole plants. Appropriate leaf and immature storage tissues were frozen for sugar and enzyme analyses as previously described $(3,2)$. Enzymes included acid phosphatase, ATP-ase, acid invertase, and beta-amylase. Trehalase (6) was also assayed. All replicated data were submitted to statistical analysis. 


\section{RESULTS}

An apparent growth repression was evident in Polaris-treated plants 4 days after chemical application (fig. 1). The effect attained statistical significance at 7 days.

Among tissue parameters acid invertase was the most sensitive to Polaris (table 1). Although localized in immature storage tissue, the enzyme was significantly repressed within $24 \mathrm{~h}$ after chemical administration to the leaves. Sucrose content of both leaf and immature storage tissues was significantly increased by Polaris within 2 days (fig. 2).

In addition to growth, invertase, and sucrose changes, the enzymes

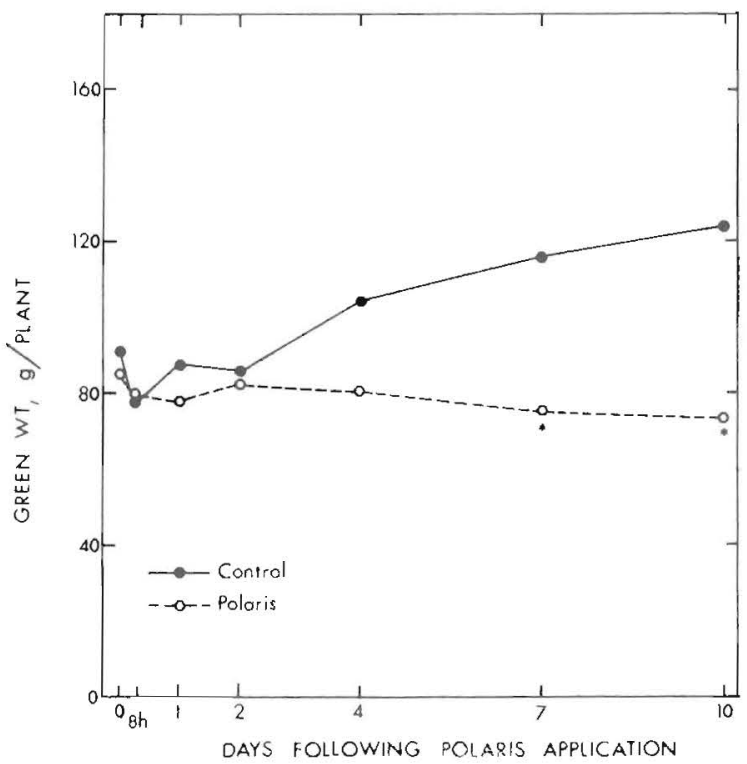

Fig. 1.-Time-course for the induction of growth restraint by Polaris in early-juvenile sugarcane. Symbols: (O) control; (O) Polaris; $\left({ }^{*}\right)$ significant deviation from control, P $<.05$.

trehalase and ATP-ase declined from 4 and 7 days onward, respectively, as "late" responses to the ripener (fig. 2). These effects were confined to immature storage tissue. There was little evidence of Polaris action upon leaf enzymes during the 10-day interval (table 1).

\section{DISCUSSION}

THEORETICAL CONSIDERATIONS

Propagation of early-juvenile plants by sand culture yields extremely rapid growth during the Puerto Rico summer (from early May through 
TABLE 1.-Effects of Polaris on enzyme activity in early-juvenile sugarcane during the first 10 days following application

\begin{tabular}{|c|c|c|c|c|c|c|c|c|c|}
\hline \multirow{3}{*}{ Tissue } & \multirow{3}{*}{$\begin{array}{l}\text { Days following } \\
\text { application }^{1}\end{array}$} & \multicolumn{8}{|c|}{ Mg product/g tissue/h, for enzyme- } \\
\hline & & \multicolumn{2}{|c|}{ Acid phosphatase } & \multicolumn{2}{|c|}{ ATP-ase } & \multicolumn{2}{|c|}{$\beta$-amylase } & \multicolumn{2}{|c|}{ Trehalase } \\
\hline & & Control & Polaris & Control & Polaris & Control & Polaris & Control & Polaris \\
\hline \multirow[t]{8}{*}{ Leaf } & 0 & 2.4 & 2.5 & 8.1 & 7.1 & 296 & $227^{*}$ & 0.132 & 0.158 \\
\hline & $8 \mathrm{~h}$ & 2.9 & 2.6 & 8.0 & 6.6 & 246 & 282 & .155 & .203 \\
\hline & 1 & 2.3 & 2.5 & 6.0 & 6.9 & 234 & 287 & .143 & .238 \\
\hline & 2 & 2.3 & 2.3 & 6.5 & 7.2 & 210 & 241 & .212 & .175 \\
\hline & 4 & 2.5 & 2.5 & 7.0 & 6.3 & 225 & 234 & .245 & $.150^{* 2}$ \\
\hline & 7 & 2.1 & 2.1 & 6.2 & 5.1 & 282 & 231 & .192 & .160 \\
\hline & 10 & 2.3 & 2.3 & 5.9 & 5.4 & 213 & 237 & .228 & .233 \\
\hline & & \multicolumn{2}{|c|}{ Acid invertase } & & & & & & \\
\hline \multirow[t]{7}{*}{ Immature storage } & 0 & 12.1 & 12.8 & 13.0 & 11.4 & 802 & 842 & 3.2 & 4.0 \\
\hline & $8 \mathrm{~h}$ & 6.0 & 6.9 & 10.0 & 9.1 & 765 & 796 & 3.1 & 2.8 \\
\hline & 1 & 10.6 & $8.3^{*}$ & 10.3 & 9.3 & 822 & $734^{*}$ & 2.9 & 3.6 \\
\hline & 2 & 12.4 & $6.5^{*}$ & 9.7 & 8.3 & 774 & 704 & 3.2 & 2.5 \\
\hline & 4 & 13.9 & $5.6^{*}$ & 7.7 & 8.1 & 868 & 757 & 2.0 & $1.0^{*}$ \\
\hline & 7 & 11.2 & $5.3^{*}$ & 6.9 & 5.5 & 776 & 700 & 1.8 & $.7^{*}$ \\
\hline & 10 & 10.4 & $6.5^{*}$ & 8.4 & $4.8^{*}$ & 805 & 739 & 2.0 & $.7^{*}$ \\
\hline
\end{tabular}

${ }^{1}$ Polaris was administered at $0630 \mathrm{~h}$ as an aqueous foliar spray containing $3000 \mathrm{p} / \mathrm{m}$ active ingredie
to spray application at $0630 \mathrm{~h}$, the second at $1430 \mathrm{~h}$. All subsequent harvests were made at $0630 \mathrm{~h}$.

$2 *$ Indicates a significant deviation of the Polaris value from that of the control at the same harvest $(\mathrm{P}<.05)$. 

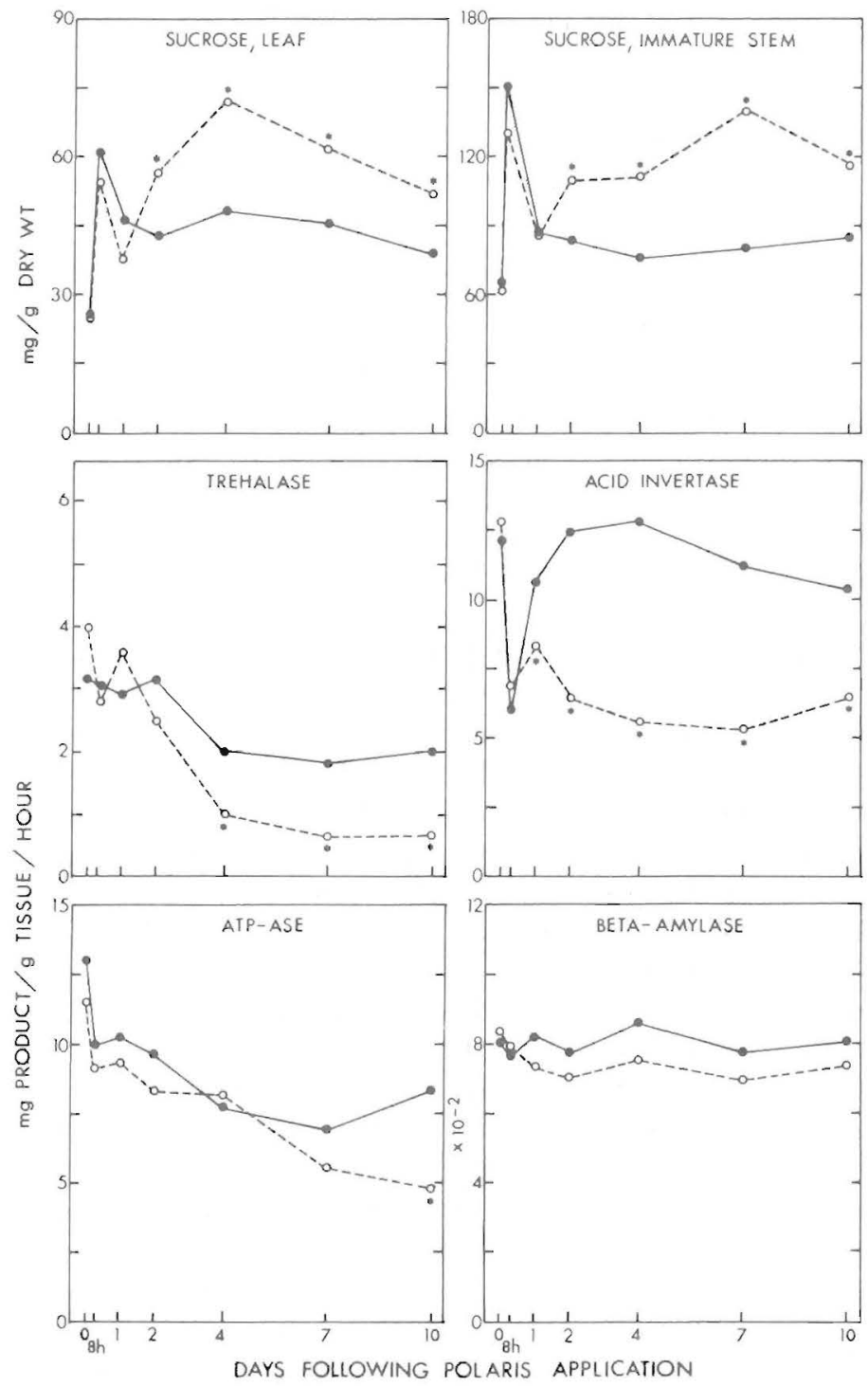

Frg. 2.-Time-course for the induction of sucrose increases in leaf and immature storage tissue, and enzyme repression in immature storage tissue, by Polaris administered to early-juvenile sugarcane. Symbols: (O) control; (O) Polaris; $\left({ }^{*}\right)$ significant deviation from control, $\mathrm{P}<.05$.

September). A 6- to 8-week old plant will double its mass in approximately 16 days. It therefore offers a highly effective model for detection of growth-regulatory activity, that is, a control plant will quickly outdistance a treated plant encountering some form of growth obstruc- 
tion. Because adult plants cannot reflect such changes so quickly, it can be argued that early-juvenile plants are not valid models for measuring the inductive or persistence potentials of a chemical ripener. On the contrary, the fundamental tasks confronting the ripener in altering sucrose production and storage systems are basically the same. It is the adult plant that constitutes a disadvantaged model, first by virtue of its enormous mass, and second by the limitations of conventional parameters for rapid detection of its growth and qualitative changes.

\section{BIOCHEMICAL TIME-COURSE FOR RIPENING POTENTIATION}

A major factor in the Polaris induction of a sucrose-accumulating regime was the repression of acid invertase (fig. 2). This is a multidimensional task involving spatial factors as well as qualitative enzymic regulation. The rapidity with which Polaris accomplished this-in plants intensively geared for sucrose utilization rather than storage-is remarkable.

Acid invertase ordinarily fluctuates about seven-fold between mid morning and mid afternoon $(19,5)$. This natural flexibility is probrbly influenced by many factors, but a highly sensitive hormonal rogulation of invertase m-RNA appears to be decisive (7, pp 380-2). Invertase samples harvested $8 \mathrm{~h}$ after Polaris application show a normal afternoon decline unaltered by Polaris (fig. 2), followed by significant repression wichin the subsequent $16 \mathrm{~h}$. Sucrose increases had not yet occurred at $24 \mathrm{~h}$ when invertase repression was underway.

The most accurate concept of sucrose accumulation processes is depicted by the "sugar accumulation cycle" developed by Glasziou and his coworkers in Australia (14, 7, pp 332-56). Acid invertase contributes to the stepwise transfer of sucrose from the outer space, or conducting phloem, to inner space deposition in vacuoles of storage parenchyma tissue. The enzyme is found in vascular tissue, free space of cell walls, the metabolic or cytoplasmic region of storage cells, and cell vacuoles. Acid invertase is particularly prominent in immature storage tissue (12) where it catalyzes sucrose inversion in the outer space prior to its movement into the storage vacuole (18). Because sucrose storage processes are reversible, the equilibrium in rapidly-expanding tissues will favor utilization, or withdrawal, in support of growth and respiratory activity. Hence, the tasks of Polaris must include a restriction of sucrose inversion in the storage compartment without obstructing the outer space inversion necessary for continued sugar influx. In the present study, Polaris completed the qualitative and spatial requirements of inversion control within $48 \mathrm{~h}$, the time in which significant sucrose increases were first recorded (fig. 2). 
These changes would not have been detected in comparably treated adult plants where the millable stalk served as sample material. They would be detected in the uppermost leaves and expanding stem tissues having comparable age to those presently employed. It is concluded that, when adequately administered, Polaris will set the stage for sucrose accumulation to proceed within about $48 \mathrm{~h}$ after application.

\section{FOLIAR SUCROSE INCREASES}

Evidence of Polaris activity in source tissues spatially and biochemically removed from inversion control is found in the rapid increase of leaf sucrose (fig. 2). The gains were statistically significant from $48 \mathrm{~h}$ onward, coinciding in time with sucrose changes in immature storage tissue. No biochemically-related parameter was available for leaf sucrose with a chemical sensitivity comparable to the acid invertase of immature storage tissue.

Foliar sucrose increases are not attributable to a repressed acid invertase, which in any case is not found in sugarcane leaves. They possibly involve a modification of the photosynthetic unit. Such an effect is consistent with the contributions of light in Polaris action reported earlier $(8,9)$. It is also possible that Polaris enhances sucrose synthetase or other systems operating at sub-optimal rates in sucrose biosynthesis. On the other hand, action spectra for ${ }^{14} \mathrm{Co}_{2}$ assimilation in sugarcane leaves reflect a fluent passage of ${ }^{14} \mathrm{C}$ into sucrose throughout the visible light spectrum (unpublished). This suggests that sucrose biosynthesis per se is not a rate-limiting process subject to improvement by chemical means. A key to Polaris action in leaf tissues might well be found in the photosynthetic light reactions upon which carbon reduction is predicated.

\section{TIME-COURSE FOR GROWTH VS. QUALITATIVE CHANGES}

The Polaris induction of significant growth decline within 7 days (fig. 1) is also remarkable when viewed in perspective, that is, when green weight is taken as a summary product of biochemical and physiological changes occurring much earlier. Acid invertase repression is again a decisive factor. This enzyme is very intimately involved in tissue expansion $(13,16)$, probably assuming rate-limiting proportions under changing seasonal conditions (15). Presumably, this involves a denial of inverted sucrose as a carbon source for support of growth processes. The decline of soluble protein from the fourth day onward in expanding internode tissue (table 2) is consistent with this view. The preferential status of sucrose as the supporting carbon source is reflected in the hexose levels which remain stable even after inversion is vastly curtailed (table 2). Within this framework the growth effect of Polaris, following 
upon invertase repression at $24 \mathrm{~h}$ and sucrose increases at $48 \mathrm{~h}$, becomes a consequence rather than a cause of the events leading to higher quality cane.

Polaris is technically marketed as a "plant growth regulator". The incidental nature of its growth-regulating properties in chemical ripening is seemingly academic - so long as one deals only with early-juvenile plants. In a broader sense both the chemical manufacturer and the sugar planter stand to profit by closer inspection of growth vs. ripening attributes of candidate ripeners. In product development, for example,

TABLE 2.-Effects of Polaris on soluble protein and reducing-sugar components of early-juvenile sugarcane

\begin{tabular}{|c|c|c|c|c|c|}
\hline \multirow{3}{*}{ Tissue } & \multirow{3}{*}{$\begin{array}{l}\text { Days following } \\
\text { application }\end{array}$} & \multicolumn{4}{|c|}{$\mathrm{Mg} / \mathrm{g}$ dry wt, for- } \\
\hline & & \multicolumn{2}{|c|}{ Soluble protein } & \multicolumn{2}{|c|}{ Reducing sugars } \\
\hline & & Control & Polaris & Control & Polaris \\
\hline \multirow[t]{7}{*}{ Leaf } & 0 & 3.7 & 3.6 & 10.7 & 11.2 \\
\hline & $8 \mathrm{~h}$ & 3.7 & 3.7 & 10.3 & 11.4 \\
\hline & 1 & 3.7 & 5.1 & 10.8 & 11.8 \\
\hline & 2 & 4.2 & 5.5 & 11.0 & 13.1 \\
\hline & 4 & 5.5 & 6.6 & 11.7 & 15.6 \\
\hline & 7 & 5.1 & 6.7 & 15.7 & 18.9 \\
\hline & 10 & 7.3 & $10.1^{* 2}$ & 16.5 & $19.9 *$ \\
\hline \multirow[t]{7}{*}{ Immature storage } & 0 & 37.8 & 40.0 & 21.5 & 27.3 \\
\hline & $8 \mathrm{~h}$ & 29.0 & 32.8 & 23.6 & 22.6 \\
\hline & 1 & 30.8 & 28.5 & 24.1 & 22.3 \\
\hline & 2 & 35.0 & 32.5 & 24.1 & 22.5 \\
\hline & 4 & 42.8 & 30.2 & 26.5 & 23.4 \\
\hline & 7 & 42.3 & $26.7^{*}$ & $25.1^{\circ}$ & 24.4 \\
\hline & 10 & 47.0 & $23.6^{*}$ & 23.6 & $28.7^{*}$ \\
\hline
\end{tabular}

${ }^{2}$ Polaris was administered at $0630 \mathrm{~h}$ as an aqueous foliar spray containing $3000 \mathrm{p} / \mathrm{m}$ active ingredient plus $0.1 \%$ Tween 20 .

$2 *$ Indicates a significant deviation of the Polaris value from that of the control at the same harvest $(\mathrm{P}<.05)$.

materials that will improve the photosynthetic unit, or generally enhance sucrose manufacture, or perhaps encourage the utilization of sugars other than sucrose for growth support, will have definite advantages over growth regulators. At the plantation level, materials offering a range of source-to-sink attributes should produce indefinitely without increasing the hazards of tonnage loss which accompany prolonged treatments with growth inhibitors.

\section{RESUMEN}

El tiempo que Polaris (N, N-bis [fosfonometil] glicina) toma para la inducción de cambios en el crecimiento, la sacarosa y los enzimas se examinó en plantitas de caña de azúcar sem- 
bradas en arena. El compuesto comercial madurativo se aplicó en una aspersión foliar acuosa que contenía 3,000 p.p.m. del ingrediente activo. Muestras de las plantas se cosecharon inmediatamente antes de la aplicación y de 8 horas a 10 días más tarde. La invertasa ácida disminuyó significativamente dentro de 24 horas y la sacarosa aumentó tanto en las hojas como en las cañas inmaturas dentro de 48 horas. Los enzimas trehalasa y ATP-asa, y la proteína soluble fueron restringidos en las cañas inmaturas a partir del cuarto día. Una restricción significativa en crecimiento se obtuvo al séptimo día. La rapidez de acción de Polaris se discute dentro del contexto de discretas funciones bioquímicas y espaciales que pueden tener lugar en una planta joven tomada como un sistema modelo.

\section{LITERATURE CITED}

1. Alexander, A. G., and Montalvo-Zapata, R., Studies on the activity of CP 41845 in early-juvenile sugarcane, Crop Sci. 12: 677-80, 1972.

2. - and - A role for sugarcane plantlets in the rapid screening of chemical ripeners, Proc. P.R. Sugar Technol. Assoc., November 1972.

3. - and - Evaluation of chemical ripeners for sugarcane having constant nitrogen and moisture regimes. I. Growth, quality, and enzymic responses of nine potential ripeners, Tropical Agr. (Trinidad) 50 (1): 35-44, 1973.

4. - and - Evaluation of chemical ripeners for sugarcane having constant nitrogen and moisture regimes. II. Superior activity of CP 41845 (Monsanto), Tropical Agr. (Trinidad) 50 (4): 307-18, 1973.

5. - - - and Justiniano, M. G., Diurnal behavior of sugarcane acid invertase, J. Agr. Univ. P.R. 57 (1): 84-6, 1973.

6. - Studies on trehalase in Saccharum spp leaf and storage tissue, Plant and Cell Physiol. 14: 157-68, 1973.

7. - Sugarcane Physiology. A comprehensive study of the Saccharum source-to-sink system, Elsevier Scientific Publishing Co., Amsterdam, 1973.

8. - and Biddulph, O., Effects of growth-regulatory chemicals on the action spectra for ${ }^{14} \mathrm{C}$ assimilation and transport in sugarcane leaves, J. Agr. Univ. P.R. 54 (1): 1425. 1975.

9. - Efficiency of chemical ripener action in sugarcane. I. Growth and qualitative responses to Polaris applied at different hours of the day, J. Agr. Univ. P.R. 60 (4): $460-8,1976$.

10. - - Efficiency of chemical ripener action in sugarcane. III. Growth and quality effects of Polaris as a function of the number and frequency of ap slication. (Submitted for publication J. Agr. Univ. P.R., Jan. 22, 1976.)

11. Anonymous, More sucrose with Polaris, commercial release by Monsanto Agricultural Products Co., January 1975.

12. Glasziou, K. T., Accumulation and transformation of sugars in sugarcane stalks: Mechanism of inversion of sucrose in the inner space, Nature 193: 1100, 1962.

13. - and Bull, T. A., The relation between total invertase activity and internode expansion in sugarcane stalks, Proc. Int. Soc. Sugar Cane Technol. 12: 575-81, 1967.

14. - and Gayler, K. R., Storage of sugars in stalks of sugarcane, Bot. Rev. 38 (4): $471-$ 90, 1972.

15. Hatch, M. D., Sacher, J. A., and Glasziou, K. T., Sugar accumulation cycle in sugarcane. I. Studies on enzymes of the cycle, Plant Physiol. 38 (3): 338-43, 1964.

16. - and Glasziou, K. T., Sugar accumulation cycle in sugarcane. II. Relationship of invertase activity to sugar content and growth rate in storage tissue of plants grown in controlled environments, Plant Physiol. 38: 344-8, 1964.

17. Orr, J. P., Breakthrough in sugarcane production technology announced by Monsanto, News Release, Monsanto Agricultural Products Co., Public Relations Department, March 11, 1975. 
18. Sacher, J. A., Hatch, M. D., and Glasziou, K. T., Sugar accumulation cycle in sugarcane. III. Physical and metabolic aspects of cycle in immature storage tissues, Plant Physiol. 38 (3): 384-454, 1963.

19. Slack, C. R., The physiology of sugarcane. VIII. Diurnal fluctuations in the activity of soluble invertase in elongating internodes, Aust. J. Biol. Sci. 18: 781-8, 1965. 